\title{
Influence of the Organization of Actors in the Ecological Outcomes of Investment in Restoration of Biodiversity
}

\author{
Scemama Pierre ${ }^{1,{ }^{*}}$, Levrel Harold ${ }^{2}$
}

${ }^{1}$ Ifremer, Univ Brest, CNRS, UMR 6308, AMURE, Unité d'Economie Maritime, IUEM, 29280, Plouzane, France

${ }^{2}$ CIRED, AgroParisTech, CNRS, EHESS, Ecole des Ponts ParisTech, Univ Paris-Saclay, UMR 8568

CIRED, Campus du Jardin Tropical, 45 bis, avenue de la Belle Gabrielle, 94736 Nogent-sur-Marne, France

*Corresponding author : Scemama Pierre, email address : pierre.scemama@ifremer.fr

\begin{abstract}
:
This paper investigates the consequences of the organization of actors on the performances of biodiversity restoration projects. It leans on an interdisciplinary framework that uses ecological engineering information to answer an economic issue following the transaction cost economics framework. Applied to four case studies, this analysis allows us to establish a direct link between the organization of restoration projects and their ecological performance and in fine on their reproducibility. In the end we show that projects that are embedded within flexible organizational forms are in phase with ecological engineering principles and are more likely to be replicated. This focus on the organization of actors in restoration projects provides new insights to foster investment in biodiversity restoration.
\end{abstract}

\section{Highlights}

- Transaction cost economics allows the integration of ecological and economic sciences in an analytical framework for biodiversity conservation. Projects embedded within flexible organization and complying with ecological engineering are more likely to be replicate. Projects coordinated by formal organizations are further from ecological engineering and more idiosyncratic.

Keywords : Biodiversity restoration, Organization, Transaction costs, economics, Ecological engineering 


\section{Introduction}

Estimates suggest that the world have lost around 50\% of its wetlands since 1900 (Russi et al. 2012). This erosion of natural capital is related to two phenomena: on the one hand, increasingly degrading stress on wetlands (Sala et al. 2000) and on the other hand, the lack of investment in the green infrastructures ${ }^{1}$ formed by these ecosystems (Neßhöver et al., 2009). Consequently, different policy frameworks have tried to promote investment in biodiversity. At the international level, the Convention on Biological Diversity has established a strategic plan for the 2011 - 2020 that encompasses the restoration of at least $15 \%$ of degraded ecosystems (CBD 2011).

To comply with these objectives, regulatory frameworks have emerged at national levels to integrate investment in biodiversity restoration, for example, through compensation schemes (McKenney and Kiesecker, 2009) and payments for environmental services (Engel et al., 2008). In parallel, scientists have shown evidence of the effectiveness of biodiversity restoration, with respect to both its ecological and economic dimensions. Indeed, scientists have investigated the ecological efficacy of investing in biodiversity restoration (Benayas et al. 2009; Jones et Schmitz 2009; Moreno-Mateos et al. 2012). Furthermore, several works have shown that the benefits obtained outweigh the costs (Aronson et al. 2010; De Groot et al. 2013). Despite this promising background, there appears to be little hope of reaching the objective of $15 \%$ restoration (Leadley et al., 2014).

One major explanation is that although focusing on proving that the benefits of restoration exceed its costs, economic arguments completely ignore the organizational dimension of biodiversity restoration ${ }^{2}$. Transaction Cost Economics (TCE) places the study of alternative forms of organizations and their relative transaction costs at the heart of its research agenda (Williamson 1985; Ménard and Sirley 2005). Transaction costs are the costs of implementing

\footnotetext{
${ }^{1}$ As we apply our study to aquatic ecosystems the more accurate term should be "blue infrastructure" however here we follow da Silva and Wheeler (2017) recommendation to use "green infrastructure" as a broad concept that include all operations related to ecological, natural or blue infrastructures.

${ }^{2}$ Moreover, this focus on cost-benefit analysis can jeopardize ambitious objectives in environmental policies (Feuillette et al., 2016).
} 
the investment project, i.e. the costs of planning, adapting and controlling transactions corresponding to this investment (Williamson 1985). The theoretical answer to high transaction costs is to shift to another more efficient organization (market, vertical integration or hybrid governance). However, this is not always possible. In this case actors can (1) modify the characteristics of transactions to align them with the organization (Yvrande-Billon and Ménard, 2005), or (2) they can abandon the transaction if the transaction costs - once added to production costs - are higher than the expected gains (Dahlman, 1979). Transaction costs can therefore be critical regarding the decision to invest in biodiversity restoration.

When considering the performance of biodiversity restoration, Ecological Engineering (EE) specialists have worked on developing sets of guidelines for successful project design (Bergen et al. 2001; Mitsch 2012; Riley 2016). Regarding investment in ecosystems, ecological engineering groups scientists and practitioners whose objective is "the design of sustainable ecosystems that integrate human society with its natural environment for the benefit of both" (Mitsch, 2012). The goals of EE are the restoration of ecosystems damaged by human activities and the creation of new sustainable ecosystems that have both human and ecological values.

Our goal is therefore to better understand how organizations and their transaction costs can influence the ecological performance of EE projects. To address this issue, we have developed an original interdisciplinary framework that mobilizes EE information on the design of biodiversity restoration projects to answer a common economic question with respect to institutional arrangements based on a transaction cost analysis. In the first section of this paper we present the analytical framework built on the basis of TCE arguments with EE principles. The second section presents an illustration of the application of this framework to four case studies. Finally, the last section discusses the results and their policy and research implications. 


\section{Analytical framework}

\subsection{The problem of transaction costs}

The question of the organization of transactions was first raised by Coase (1932), who explained that the limits of the market to coordinate economic activities and resource allocation were due to the existence of transaction costs. Transaction costs are the costs of planning, adapting and controlling transactions (Williamson 1985). There are three categories of organization and each of them relies on specific coordination devices: the market (decentralized organization relying on incentives and autonomous adaptation), hierarchy (firm or administration, using control and formal coordination), hybrid forms (crossing market and hierarchy characteristics). According to TCE, partners adopt the organization that will minimize transaction costs.

One problem is that these costs are difficult to measure directly (Masten et al., 1991). The strength of the theory is that it entails studying organizational choices according to the observable characteristics of transactions, namely the specificity of investments and the level of uncertainty in the transaction. Each type of organization has a different level of efficiency regarding the characteristics of the transaction. Markets support the lowest transaction costs when investments are non-specific (i.e. easily re-deployable) and uncertainty is low. But as specificity and uncertainty increase, autonomous markets are supplanted by more complex forms of governance: integration in the hierarchic structure of the firm becomes more efficient.

In the case of investment in biodiversity, a growing literature has shown that projects are mostly governed by hybrid forms (Muradian et Rival, 2012; Scemama et Levrel, 2014; Vaissière et Levrel, 2015). Hybrid forms combine the coordination devices of markets and hierarchies to deal with different degrees of investment specificity. The wide range of hybrid forms was described by Ménard (2004). They all involve the creation of specific mechanisms designed for coordinating activities, organizing transactions and solving disputes. Ménard (2004) showed the presence of a governance body which is more or less formalized and powerful regarding decision-making. When specificity is low but too high for the market, we find hybrids that primarily rely on trust, where decisions are decentralized, and coordination 
is implemented through mutual influence and reciprocity. As specificity increases, hybrids are progressively dominated by more and more formal administration: a relational network, then a leader and finally a governing body, until specificity becomes too high and hierarchy becomes the most efficient form.

The choice of organization follows a discriminating alignment regarding transaction characteristics (Williamson, 1985). However, these characteristics are endogenous to organizational choice, meaning that decisions regarding organizational form and investment are simultaneous. As a result, if organizational adaptation is not possible because of institutional constraints, for example, partners can modify the characteristics of transactions to align them with the organization (Yvrande-Billon and Ménard, 2005). As a result, when it comes to the design of the investment, the choice of organization and setting the characteristics of the project are simultaneous (Figure 1).

The efficiency of an organization can also be influenced by the institutional environment (North, 1991). Institutions are defined as "the humanly devised constraints that structure political, economic and social interaction" (North, 1991, p.1). They form the matrix of incentives and constraints in which an organization can evolve. The efficiency of organizations regarding given transaction characteristics can be modified by institutional changes as they can affect transaction costs (Ménard, 2003). Public policies can modify the institutional environment and thus force actors to adapt to changes in transaction costs.

From this perspective, we want to build an interdisciplinary analytical framework that explains what this simultaneous choice means for the characteristics of EE projects. Measuring the interaction between the level of uncertainty and specificity and the organization of transactions is subject to several theoretical and empirical difficulties. As underlined by Shelanski and Klein (1995), the major difficulty is that uncertainty and asset specificity are difficult to measure consistently across firms and industries. Moreover, many studies rely on surveys or interviews ${ }^{3}$, thus their results are subject to the respondent's beliefs rather than to their observable choices. Such a framework should pay attention to the different dimensions of uncertainty (Sutcliffe and Zaheer, 1998) and asset specificity (De

\footnotetext{
${ }^{3}$ In an exhaustive review De Vita et al. (2011), observed that asset specificity was mostly measured using ad hoc surveys with an aggregated approach.
} 
Vita et al., 2011), as they may not have the same effects on organizational arbitration. Additionally, uncertainty and asset specificity should be considered simultaneously, as it is their combination that raises transaction costs (Shelanski and Klein, 1995). This calls for the development of an industry dependent framework - in this case ecological engineering - in which we can rely on objective and observable information to explain why specificity and uncertainty can cause coordination problems and increase transaction costs.

Moreover, putting ecological engineering at the heart of the analysis allows us to discuss the link between the quality of investment in ecosystems - measured according to its correspondence to EE principles - and the organizational mode of the project. From this perspective, we build an analytical framework that uses EE information to contribute to TCE analysis (Figure 2). We start by building the framework on the basis of a bilateral dialogue between the literature on EE and TCE.

\subsection{Specificity and ecological engineering}

Asset specificity is the most important source of transaction cost to consider when studying how a given transaction should be organized (Williamson, 1985). A specific investment is defined as a long-term and specialized investment that cannot be redeployed for an alternative use without the loss of its productive value. When a transaction requires specific investments, the partners will want to protect them - i.e. the rent associated with these investments - thus binding the partners in a lock-in situation where nobody gains an advantage from breaking the relationship but where one partner can adopt opportunistic behavior to exploit the dependence of the other. This is why partners protect the investment with certain coordination devices that raise transaction costs. According to TCE, high specificity results in idiosyncratic transactions (Williamson, 1981) which is a problem in a context where we want to stimulate investment.

We have to consider different dimensions of specificity in EE projects (Table 1; Coggan et al., 2013; Scemama et Levrel, 2014) that are linked to natural capital (the ecosystem) and accompanying human and manufactured capital. Firstly, ecosystems are by nature characterized by a high level of physical and site specificity. Indeed, they are defined by the complexity and diversity of their components and functions across time and space (Holling, 
1996, Pimm 1984). Numerous parameters - population genetics, species communities, interaction with other ecosystems - can influence ecosystem functioning and the goods and services they can provide to society (Kremen, 2005; Benett et al., 2009). The location of ecosystems influences their functioning (Mitsch et Gosselink, 2000; Moreno-Mateos et al., 2012) and their ecological interactions and resilience (Hanski et al., 1998). Secondly, EE may also involve specific human capital (Aronson et al., 2016), namely expertise in ecological design, works and project management and monitoring, and the reputation of the holders of this expertise concerning ecological performance. Thirdly, investing in biodiversity generally also involves manufactured capital that not only takes the form of standard civil engineering tools (backhoe, tractors, etc.), but which is also highly specific when tailored to a specific project.

A solution to limit the specificity of investment can be to consider investment in an ecosystem rather than investment in ecosystem services (Palmer et al., 2014). Firstly, because the ecosystem services approach requires better understanding of the links between the structure of the ecosystem, its functioning and the provision of services (de Groot et al., 2002), thus increasing the complexity of the operation. Secondly, because targeting only a subset of processes to optimize the provision of one service can limit the provision of other ecosystem services (Gilvear et al., 2013), impacting potential alternative use. Thirdly, because focusing on ecosystem services also questions their spatial distribution (Naidoo et al., 2008), increasing the site specificity of the investment. According to EE specialists, this can be done by adopting "system thinking" (Mitsch 2012; Mitsch and Jørgensen, 2004), which means stopping thinking about linear causes and effects (structure to service) and more about the ecosystem as a whole.

Another solution for decreasing the specificity of a project is to consider minimizing the need for energy and information. To minimize energy, the project should seek to benefit from natural flows of energy (Mitsch, 2012) or even from other biodiversity components as engineer (Jones et al., 1997). Furthermore, Bergen et al. (2011) defended the idea that EE could also benefit from information minimization, by increasing cooperation with natural processes and ecosystem self-organization. By following these recommendations, practitioners could develop broader knowledge and invest in common tools easier to transfer across projects, thus decreasing the specificity of human and manufactured capital. 
It is also possible to decrease the site specificity of projects by adapting the design of ecosystems to their location (Bergen et al., 2001). Taking into account the bio-geo-climatic environment in ecosystem design will decrease the complexity of a project. In addition, ecosystem designs that ignore the ecology of a place take more energy to sustain, raising management costs. Site adaptation also means that projects should take into account social and cultural contexts.

\subsection{Uncertainty and ecological engineering}

According to transaction cost theory, the other way of decreasing transaction costs is to decrease uncertainty. Indeed, specificity becomes a transaction cost issue when uncertainty around the transaction is high. It can take the project along an unexpected path that could be invoked by a party as a reason for renegotiating the initial terms of the partnership to its advantage. TCE recognizes two different types of uncertainty: environmental uncertainty due to perturbations exogenous to a partner's decision, and behavioral uncertainty due to the risk of opportunism from the partners. Transactions characterized by high uncertainty exposed to unpredictable, frequent and large disturbances - need costly coordination mechanisms that must be flexible enough to adapt (monitoring and management) while being sufficiently formalized to prevent opportunistic behaviors (enforcement and contractual adjustment).

Environmental uncertainty concerning the outcomes of EE is high due to the fact that the results of an action are frequently different from expectations (Moilanen et al., 2009). This is due to the existence of alternative equilibriums and differences in ecological dynamics between degraded and healthy ecosystems (Holling, 1996; Folke et al., 2004; Suding et al., 2004; Hildebrand et al., 2005). In this sense, it is difficult to anticipate the results of a restoration action because ecosystems can shift into several states of equilibrium from the same initial state (Folke et al., 2004; Vesk and Dorrough, 2006). Environmental uncertainty can also concern institutions and policies. Unexpected changes in the institutional environment due to the evolution of legislation or in response to judicial decisions can also affect investment in biodiversity and raise transaction costs. Finally, investment in biodiversity is also exposed to opportunistic behavior from partners that may have no interest in the ecological quality of the project (Kroeger and Casey, 2007). 
One solution for decreasing uncertainty is to shift from engineering to ecological resilience (Holling, 1996). Engineering resilience focuses on efficiency and predictability, increasing monitoring transaction costs. Ecological resilience is more about persistence, change and unpredictability, focusing on the existence of functions rather than on their optimization. Ecosystems require a large functional space, i.e. alternative functional states in which ecosystems can oscillate, allowing them to remain healthy or persist. Such practices generally leads ecosystems to lose their structural and functional diversity, affecting the ability of the system to produce the same outputs in the future (Holling, 1996). In practice, EE specialists recommend relying on the self-organizing capacity of nature (Mitsch and Jorgensen 1989); on the maturation of ecosystems that make them more diverse and resilient (Todd and Todd, 1994); and on the natural evolution of ecosystems that can occupy different functional equilibriums (Holling, 1996). The former element is associated with the argument already presented regarding specificity whereby a project should target the broad ecosystem rather than focusing on the maximization of a specific outcome (ecosystem services).

Another solution for decreasing uncertainty is to limit the number of objectives to be attained. In order to attain multiple objectives, it is better to keep design requirements independent, i.e. in this case the adjustment for one objective does not affect the other objectives. In the case of complex ecosystems with many levels of interconnection between components, this is highly unlikely (Bergen et al., 2001). Moreover, ecosystems provide bundles of ecosystem services that make the optimization of multiple services difficult (Raudsepp-Hearne et al., 2010).

It is also possible to decrease behavioral uncertainty when partners share common values and trust. In the context of $\mathrm{EE}$, those values can be connection to place, equity, sustainability and esthetics (Bergen et al., 2001). Here we emphasize that behavioral uncertainty is considered to be the most relevant form of uncertainty in the transaction context (Williamson, 1985) ${ }^{4}$.

\footnotetext{
${ }^{4}$ This is why it is considered at the end of the transaction cost argumentation: costly coordination devices that raise transaction cost are required because there is a risk that actors express a strategic behavior to their own advantage and at the expense of their partner (this risk is higher when specificity and environmental uncertainty are high).
} 


\subsection{Summary of the analytical framework}

The arguments presented in this section allow us to establish links between transaction costs and ecological principles. Table 2 gives a summary of the effect of EE compliance on the sources of transaction costs. We can see that compliance with EE principles when investing in ecosystems can decrease the specificity of investments and the uncertainty surrounding the project. In terms of organization, considering lower specificity and uncertainty, such a project would be better organized using the informal hybrid form where coordination is motivated by trust and shared values. On the other hand, projects that do not comply with EE principles require costly monitoring (to control the achievement of the ecological objectives) and even costly management (when disturbances modify ecological objectives).

In terms of transaction cost, this interpretation of EE principles means that the closer the objective of the project is to $\mathrm{EE}$, the lower the specificity, the uncertainty and the related transaction costs, and thus the further we are from hierarchical organizational forms (Figure 1).

\section{An application to wetlands restoration}

\subsection{Material and method for the case study analysis}

In order to illustrate the application of our analytical framework, we applied a multiple case study analysis to four biodiversity restoration projects in France. The formulation of our research perfectly justifies using a case study analysis (Yin, 2017): (1) our research question (how ...) requires in-depth investigation of the decision-making processes; (2) while considering multiple sources of evidence of (3) contemporary phenomena (biodiversity restoration is still in its early infancy). Moreover, case study analysis is common in TCE (Shelanski and Klein, 1995). The collection of evidence comprised interviews with key informants (regarding the coordination of actors during the project: type of contracts, day by day interactions, forms of steering comittees, etc.), on-site bibliographic studies (reports, management plans, guidelines and schedules), on-site observation and the collection of ecological data for cost-effectiveness analysis (Scemama and Levrel, 2016). These projects were selected to represent a diversity of contexts (Table 3): (1) the re-meandering of a small river in a low mountain region with high protection status; $(2)$ the rehabilitation of a coastal 
marsh in a context of intensive agriculture; (3) environmental measures to compensate and assist the expansion of port infrastructures; and (4) the creation of an elaborate wetland for the market of constructed wetlands in a Mediterranean environment. More information on each project is available in Supplementary Material.

\subsection{Vurpillères stream}

The Vurpillères stream is located in a protected area devoted to the protection of biodiversity: the Nature Reserve (NR) of Lake Remoray. In the NR, the river supplying the lake had been channeled, causing severe impacts to the surrounding marshes and bogs: lowering of the piezometric level, impacts for biodiversity in the area and downstream ecosystem services. To restore the area, the actors of the project decided to adopt a system approach. They decided to restore the stream in the hope that it would bring the whole ecosystem back to its previous state. The Vurpillères stream was the first stream to be restored.

Finally, the project was organized in compliance with the principles of ecological engineering (Table 4). No management plan was implemented as it was decided to allow the site to evolve naturally and benefit from ecosystem self-organization. In the same way, no specific monitoring was scheduled; it was integrated in the global scientific program of the Nature Reserve. The project has a low level of specificity; the partners contributed transferable knowledge and material. They are part of a long-term network in the area and will be involved in other projects relating to stream restoration, again in the area. In terms of organization, the project involved a limited number of partners whose identity matters as they are used to working together in the area. They can rely on trust and on personal motivation for coordination.

\subsection{The rehabilitation of Kervigen Marsh}

The Kervigen marsh is located close to the bay of Douarnenez in south Finistère (Brittany). The bay is particularly exposed to eutrophication problems (green algal blooms) due to the high nutrient loads released by the intensive agricultural use of the whole catchment area. The objective of rehabilitating the Kervigen marsh was to benefit from its purifying 
capacities. It is a coastal marsh covered with reeds and supplied by a catchment dominated by intensive agriculture.

The design of the project does not perfectly fit with EE principles (Table 5). It explicitly targets the purifying capacities of the system for which a sensor monitoring system was installed. The project involved building two sluices to regulate the water level in the marsh, implying a minimum amount of management. The problem of eutrophication impacts the functioning of the marsh and raises uncertainty: excess nitrate leads to the accumulation of biomass and requires regular reed mowing and removal. The specificity of the project is low; indeed, marsh restoration is the least important tool for mitigating nutrients loads in the Douarnenez bay (after the reduction of loads from households and agriculture). In terms of organization, the project was driven by a public actor in charge of the environmental management at the scale of the marsh catchment. It was the leader of the project that contracted with different actors specialized in EE and coordinated their different and separate tasks in view to mitigating nitrate pollution.

\subsection{The environmental measures of Port 2000 in the Seine estuary}

The Seine estuary is characterized by the presence of high biological diversity and by the presence on its north shore of the city of Le Havre and the port-industrial complex of the Great Maritime Port of Le Havre (GPMH). Port 2000 is an extension of the GPMH in the estuary. Environmental measures were implemented to increase its social acceptability: the creation of a resting area for birds, the creation of an artificial islet resting place for birds at the outlet of the estuary and the creation of a meander for mudflat rehabilitation.

The entire project is far from the design principals set out by EE (Table 6). Each measure was implemented to maximize several specific objectives relating to different communities of interests (e.g. harbor authorities, environmental protection actors). The measures are the result of classical engineering processes that involved costly preparation studies and heavy works, leaving little space for the self-organization of the estuary. Uncertainty around the project is high are there is no margin in the design; moreover, the partners have very different interests that expose the project to opportunistic behavior. The specificity of the 
project is also high, as if the project fails to address the environmental objective it may jeopardize future development potential in the area (Vaissière et al., 2018).

The measures took place according to a very complex organizational arrangement. Indeed, the global objectives were defined on the basis of public debate, a consultation process aimed at improving the association of the public with the construction of major projects, resulting in 42 meetings over 4 months. Moreover, an expert committee issues an advisory opinion on every decision affecting the estuary. Every measure was taken by at least three parties: the port administration, a consulting engineering expert and the construction company. We identified a very formalized "governing body" for the project: the port administration coordinates the project, seeks advices from the expert committee of the estuary, but maintains all the processes at a very formal level since its liability is engaged.

\subsection{The creation of the Saint-Just Libellule ${ }^{\circledR}$ zone}

The towns of Saint-Just and Saint-Nazaire-de-Pézan are located in the watershed of a protected Mediterranean lagoon exposed to eutrophication problems (the Or lagoon). The Libellule Zone is an original concept of constructed wetland implemented between the exit of the local wastewater treatment plant (WWTP) and the natural water network. The objective of this project is to create a mosaic of wetland habitats to apply tertiary treatment to the water discharged by the WWTP. The project is part of a research and development strategy.

The project does not exactly conform to EE principles (Table 7) but seeks to optimize different ecosystem services from different processes that drive the design of the ecosystem along a very thin line with very little space for self-organization. Consequently, preparatory studies are necessary to determine the accurate dimensioning of each wetland habitat. The structure of the habitats (e.g. the shape of the meander zone) is not determined by the natural flow but by civil works. The partners wanted to allow the system to evolve naturally, but they realized that self-organization was not compatible with ecosystem service optimization. Therefore, they had to implement management operations for both recurring and unexpected events. The project is associated with a large-scale monitoring program, since it is part of an R\&D strategy for the WWTP market and must comply with very strict 
regulations. The high specificity of the project - due to its sophisticated design - is increased by its association with the nearby WWTP which involves close monitoring of the ecosystem. In terms of organization, coordination is ensured by a formal governing body: a steering committee that incorporates all the stakeholders, takes all the decisions, and tries to satisfy all the interests, in particular due to the fact that conflicts exist around the intellectual property of the results of the R\&D program.

\subsection{Comparative analysis of case studies}

Table 8 provides a summary of the position of the four case studies in our analytical framework (Figure 2c). As discussed earlier, projects that are further from the EE principle are more likely to be coordinated by a formalized governance body. Indeed, faced with high project specificity and high uncertainty, formalized coordination has the merit of clarifying the duties and the responsibilities of each partner. But, as we underlined, the decision to invest and the organizational choice are simultaneous. Indeed, formalized coordination with numerous actors with different personal interests can lead to an accumulation of objectives in order to satisfy everybody's needs. This is perfectly clear in the case of Port 2000, where the institutional arrangement was almost settled by the public debate held (the institutional environment). A multiplicity of actors leads to a multiplicity of objectives, which increases the need for rigorous design. On the contrary, for the Vurpillères stream restoration, the long-term relationship and cooperation between the partners simplified coordination, allowing greater reliance on natural processes.

\section{Discussion and conclusion}

\subsection{An interdisciplinary framework}

This framework underlines the interest of interdisciplinarity by including biodiversity in economic analysis and, conversely, understand the economic arbitrations that biodiversity involves. Our framework shows that investigating the ecological performance of biodiversity restoration cannot forego the analysis of the performance of the different organizations, both in terms of transaction costs (economic efficiency) and in terms of their capacity to oversee ecosystem management (ecological effectiveness). Placing the ecological 
characteristics of projects at the center of the discussion makes it possible to conduct an interdisciplinary analysis in which this economic question (performance) can be discussed in parallel with an ecological diagnosis (compliance with EE principles).

This TCE approach allows better understanding of what makes a natural asset specific and how investment in an ecosystem is exposed to uncertainty. As underlined by Shelanski and Klein (1995), there is a need to develop sector dependent frameworks which implies understanding the reality of each sector. In EE projects, a large part of the problem depends on tolerance to uncertainty, as we still lack too much knowledge to pretend that we can control all the variables that might make ecosystems optimizable. If more research is needed to make more general statement following our case studies, we still provide sound assessment of the consequences of organization on the ecological performances of restoration projects.

\subsection{Perspectives regarding investment in biodiversity}

The criteria for judging the performance of an EE project are not easy to determine. The literature shows that the definition of success is strongly context dependent (Zedler, 2007; Jähnig et al., 2011). Therefore, relying on objective and observable criteria is necessary, which is why we tried to rely on the EE design principles with a "yes or no" test (Table 7). However, it is likely that compliance with each principle should be considered on a spectrum (are projects targeting functions more aligned with the EE principle than those targeting ecosystem services?). Nonetheless, this approach allows discussing the organizational issues raised by each principle in relation to specificity and uncertainty. All said and done, projects characterized by high uncertainty and high specificity are far from EE principles and thus are of less ecological interest (Mitsch 2012 in Figure 2d.).

This result is in line with our previous work (Scemama and Levrel, 2016): we analyzed the cost-effectiveness of the four case studies according to their institutional objectives. It is noteworthy that Port 2000 and the Libellule zone have a poorer cost-effectiveness ratio in comparison to the Kervigen marsh and even worse in comparison to the Vurpillères stream. In spite of the fact that new research must be performed to generalize this reasoning, one may wonder whether projects with very formal and rigid organizational forms, far from 
the precepts of ecological engineering, have higher cost-effectiveness ratios. This could provide us with a new direction in view to promoting investment in biodiversity.

One last point in the discussion on the performance of projects is that of replicability. In the current context of under-investment in biodiversity, one criterion for assessing project performance could be linked to their reproducibility. As underlined by TCT, projects characterized by high specificity and uncertainty are considered as idiosyncratic (Williamson, 1985). We should therefore promote projects that are likely to be replicated, i.e. those closer to ecological engineering principles. This is also illustrated by our case studies. In the case of the Vurpillères stream, restoration was considered successful and gave rise to similar stream restoration projects in the area (enlarging the community of practice). As for the Kervigen marsh, the performance of nutrient mitigation was so beneficial that those in charge of the watershed management plan decided to integrate more similar projects, which was not the case in other watersheds affected by eutrophication problems. Regarding the Libellule zone, most of the transaction costs were related to the R\&D nature of the project (formal coordination, confidentiality control and close monitoring of performances). Replication is therefore influenced by the organizational adaptation of the project. One solution would be to include the transaction in the governance of the WWTP. In this way the project manager could benefit from both economies of scale and added value to the WWTP. Finally, in the case of Port 2000, the environmental measures are still contested (regarding both their results and the way they were implemented) and could potentially increase future tension linked to the management of the area (Vaissière et al., 2018).

Projects coordinated with trust and shared values are more compatible with ecological engineering principles. Research on the organization of EE projects is focused on the advantages of adaptive management (Thom, 2000; Zedler 2017). Adaptive management, which can be defined simply as a learning-by-doing process, leaves space to adapt the objective of the project or the action implemented when facing uncertainty. However, it provides little information on the institutional arrangement capable of underpinning such a decision framework, possibly leading to higher costs (Thom, 2000), i.e. transaction costs. Our analysis provides better understanding of the consequences of the organizational structure on the characteristics of EE projects. Adaptive management is closer to the Vurpillère case, implying informal coordination based on trust and a relational network. 
Since the organization of projects plays an active role in their ecological performance, more attention should be given to the elements that can influence the choice of organization before the project. Like the chicken-and-egg problem, it is hard to know if the position of projects regarding EE principles is a result of their organization or the reverse. As TCE stipulates that the characteristics of the investment should be endogenous to the choice of organization, it is most likely that these choices are simultaneous. In that respect, special attention should be given to the external elements influencing these choices, which are mainly external to the projects. For example, in the case of the environmental measures of Port 2000, it is difficult to isolate the investment in biodiversity from the issues regarding the port development and the history of environmental management in the Seine estuary (Vaissière et al., 2018). Every project that invests natural capital is implemented in a specific institutional context. It is necessary to better take into account of the policy levers and barriers that influence the ecological performance of investment in biodiversity. Consequently, as hybrid forms are more adapted to the characteristics of biodiversity (Muradian and Rival, 2012; Scemama and Levrel, 2014; Vaissière and Levrel, 2015), the incentive and coercive structure of biodiversity policies should be designed to lower the transaction costs of hybrid forms of coordination devices, namely by pooling resources, contracting and competing (Ménard, 2004). Moreover, we should focus on framing projects within an organization coordinated on the basis of trust and shared values, as they are more compatible with the principles of ecological engineering.

\section{Acknowledgement}

The authors thank the French National Agency for Water and Aquatic Ecosystems (partnership Onema - Ifremer 2011) for their support in organizing this work. Thanks are also addressed to all the people interviewed for this work.

\section{$6 \underline{\text { References }}$}

Aronson, J., Blignaut, J.N., Milton, S.J., Le Maitre, D., Esler, K.J., Limouzin, A., Fontaine, C., de Wit, M.P., Mugido, W., Prinsloo, P., van der Elst, L., Lederer, N., 2010. Are Socioeconomic Benefits of Restoration Adequately Quantified? A Meta-analysis of Recent Papers (2000- 
2008) in Restoration Ecology and 12 Other Scientific Journals. Restoration Ecology 18, 143154. https://doi.org/10.1111/j.1526-100X.2009.00638.x

Aronson, J., Clewell, A., Moreno-Mateos, D., 2016. Ecological restoration and ecological engineering: Complementary or indivisible? Ecological Engineering 91, 392-395. https://doi.org/10.1016/i.ecoleng.2016.02.043

Benayas, J.M.R., Newton, A.C., Diaz, A., Bullock, J.M., 2009. Enhancement of Biodiversity and Ecosystem Services by Ecological Restoration: A Meta-Analysis. Science 325, 1121-1124. https://doi.org/10.1126/science.1172460

Benett, E.M., Peterson, G.D., Gordon, L.J., 2009. Understanding relationships among multiple ecosystem services, Ecology Letters, 12: 1394-1404, 10.1111/j.1461-0248.2009.01387.x

Bergen, S.D., Bolton, S.M., L. Fridley, J., 2001. Design principles for ecological engineering. Ecological Engineering 18, 201-210. https://doi.org/10.1016/S0925-8574(01)00078-7

CBD, 2011. Conference of the Parties Decision X/2: Strategic plan for biodiversity 2011-2020.

Coase, R.H., 1937. "The Nature of the Firm », Economica, 4, 386-405. doi:10.1111/j.14680335.1937.tb00002.x

Coggan, A., Buitelaar, E., Whitten, S., Bennett, J., 2013. Factors that influence transaction costs in development offsets: Who bears what and why? Ecological Economics 88, 222-231. https://doi.org/10.1016/i.ecolecon.2012.12.007

Da Silva, J.M.C, Wheeler, E., 2017. Ecosystems as infrastructure. Perspectives in Ecology and Conservation, 15 (1) 32-35. https://doi.org/10.1016/i.pecon.2016.11.005

Dahlman, C.J., 1979. The Problem of Externality. Journal of Law and Economics 22, 141-162.

De Groot, R.S., Blignaut, J., Van Der Ploeg, S., Aronson, J., Elmqvist, T., Farley, J., 2013. Benefits of Investing in Ecosystem Restoration. Conservation Biology 27, 1286-1293. https://doi.org/10.1111/cobi.12158 
De Groot, R.S., Wilson, M.A., Boumans, R.M., 2002. A typology for the classification, description and valuation of ecosystem functions, goods and services. Ecological Economics, 41 (3) 393-408.

de Vita, G., Tekaya, A., Wang, C., 2011. The many faces of asset specificity: a critical review of key theoretical perspectives. International Journal of Management Reviews 13, 329-348.

Engel, S., Pagiola, S., Wunder, S., 2008. Designing payments for environmental services in theory and practice: An overview of the issues. Ecological Economics 65, 663-674. https://doi.org/10.1016/j.ecolecon.2008.03.011

Folke, C., Carpenter, S., Walker, B., Scheffer, M., Elmqvist, T., Gunderson, L., Holling, C.S., 2004. Regime Shifts, Resilience, and Biodiversity in Ecosystem Management. Annual Review of Ecology, Evolution, and Systematics 35, 557-581.

Gilvear, D.J., Spray, C.J., Cases-Mulet., R., 2013. River rehabilitation for the deliveryof multiple ecosystem services at the river network scale. J. Environ. Manage.126, 30-43.

Hanski, I., 1998. Metapopulation dynamics, Nature, 396 (6706) 41-49.

Hilderbrand, R.H., Watts, A.C., Randle, A.M., 2005. The Myths of Restoration Ecology. Ecology And Society 10, 19.

Holling, C., 1996. Engineering resilience versus ecological resilience, in: Engineering within Ecological Constraints. P.C. Schulze, Washington, DC, pp. 32-45.

Jähnig, S.C., Lorenz, A.W., Hering, D., Antons, C., Sundermann, A., Jedicke, E., Haase, P., 2011. River restoration success: a question of perception. Ecological Application, 21(6) 20072015.

Jones, C.G., Lawton, J.H., Shachak, M., 1997. Positive and negative effects of organisms as physical ecological engineers. Ecology, 78 (7) 1946-1957.

Jones, H.P., Schmitz, O.J., 2009. Rapid Recovery of Damaged Ecosystems. PLoS ONE 4, e5653. https://doi.org/10.1371/journal.pone.0005653 
Kremen, C., 2005. Managing ecosystem services: what do we need to know about their ecology? Ecology Letters, 8: 468-479.

Kroeger, T., Casey, F., 2007. An assessment of market-based approaches to providing ecosystem services on agricultural lands », Ecological Economics 64 (2) 321-332.

Leadley, P.W., Krug, C.B., Alkemade, R., Pereira, H.M., Sumaila, U.R., Walpole, M., Marques, A., Newbold, T., Teh, L.S., van Kolck, J., 2014. Progress towards the Aichi Biodiversity Targets: An assessment of biodiversity trends, policy scenarios and key actions. Secretariat of the Convention on Biological Diversity.

Masten, S.E., Meehan, J.W., Snyder, E.A., 1991. The Costs of Organization. Journal of Law, Economics, \& Organization 7, 1-25.

McKenney, B.A., Kiesecker, J.M., 2009. Policy Development for Biodiversity Offsets: A Review of Offset Frameworks. Environmental Management 45, 165-176. https://doi.org/10.1007/s00267-009-9396-3

Ménard, C., 2003. "Économie néo-institutionnelle et politique de la concurrence les cas des formes organisationnelles hybrides ", Économie Rurale, 277, 45-60. doi:10.3406/ecoru.2003.5435

Ménard, C., 2004. The Economics of Hybrid Organizations. j inst theor econ 160, 345-376. https://doi.org/10.1628/0932456041960605

Ménard, C., Shirley, M.M., 2005. Handbook of New Institutional Economics. Springer.

Mitsch, W.J., 2012. What is ecological engineering? Ecological Engineering, Ecological Engineering--Its Development, Applications and Challenges 45, 5-12. https://doi.org/10.1016/j.ecoleng.2012.04.013

Mitsch, W.J., Gosselink, J.G., 2000. The value of wetlands: importance of scale and landscape setting, Ecological Economics, 35 (1) 25-33.

Mitsch, W.J., Jørgensen, S.E., 1989. Ecological Engineering: An Introduction to Ecotechnology. John Wiley \& Sons, Inc., New York, 472 pp. 
Mitsch, W.J., Jørgensen, S.E., 2003. Ecological engineering: A field whose time has come. Ecological Engineering, The Philosophy and Energence of Ecological Engineering 20, 363377. https://doi.org/10.1016/i.ecoleng.2003.05.001

Mitsch, W.J., Jørgensen, S.E., 2004. Ecological Engineering and Ecosystem Restoration. John Wiley \& Sons, Inc., New York, 411 pp.

Moilanen, A., van Teeffelen, A.J.A., Ben-Haim, Y., Ferrier, S., 2009. How Much Compensation is Enough? A Framework for Incorporating Uncertainty and Time Discounting When Calculating Offset Ratios for Impacted Habitat. Restoration Ecology 17, 470-478. https://doi.org/10.1111/i.1526-100X.2008.00382.x

Moreno-Mateos, D., Power, M.E., Comin, F.A., Yockteng, R., 2012. Structural and functional loss in restored wetland ecosystems. PLoS biology 10, e1001247

Muradian, R., Rival, L., 2012. Between markets and hierarchies: The challenge of governing ecosystem services. Ecosystem Services 1, 93-100. https://doi.org/10.1016/i.ecoser.2012.07.009

Naidoo, R., Balmford, A., Ferraro, P.J., Polasky, S., Ricketts, T.H., Rouget, M., 2006. Integrating economic costs into conservation planning. Trends in Ecology and Evolution, 21 (12) 681-687.

Neßhöver, C., Aronson, J., Blignaut, J., Lehr, D., Vakrou, A., Wittmer, H., 2009. Investing in ecological infrastructure, in: TEEB - The Economics of Ecosystems and Biodiversity for National and International Policy Makers. Earthscan, London, U.K. and Washington, D.C., pp. 401-448.

North, D., 1991. « Institutions », Journal of Economic Perspectives, 5, 97-112.

Palmer, M.A., Filoso, S, Fanelli, R.M., 2014. From ecosystems to ecosystem services: Stream restoration asecological engineering. Ecological Engineering 65, 62-70.

Pimm, S.L., 1984. The complexity and stability of ecosystems. Nature 307, 321-326. https://doi.org/10.1038/307321a0 
Raudsepp-Hearne, C., Peterson, G.D., Bennett, E.M., 2010. Ecosystem service bundles for analyzing tradeoffs in diverse landscapes. Proc Natl Acad Sci U S A 107, 5242-5247. https://doi.org/10.1073/pnas.0907284107

Riley, A.L., 2016. Restoring Neighborhood Streams: Planning, Design, and Construction. Island Press.

Russi D., ten Brink P., Farmer A., Badura T., Coates D., Förster J., Kumar R. and Davidson N. (2013) The Economics of Ecosystems and Biodiversity for Water and Wetlands. IEEP, London and Brussels; Ramsar Secretariat, Gland.

Sala, O.E., Chapin, F.S., Armesto, J.J., Berlow, E., Bloomfield, J., Dirzo, R., Huber-Sanwald, E., Huenneke, L.F., Jackson, R.B., Kinzig, A., Leemans, R., Lodge, D.M., Mooney, H.A., Oesterheld, M., Poff, N.L., Sykes, M.T., Walker, B.H., Walker, M., Wall, D.H., 2000. Global Biodiversity Scenarios for the Year 2100. Science 287, 1770-1774. https://doi.org/10.1126/science.287.5459.1770

Scemama, P., Levrel, H., 2014. L'émergence du marché de la compensation des zones humides aux États-Unis : impacts sur les modes d'organisation et les caractéristiques des transactions. Revue d’Economie Politique 123, 893-924.

Scemama, P., Levrel, H., 2016. Using Habitat Equivalency Analysis to Assess the Cost Effectiveness of Restoration Outcomes in Four Institutional Contexts. Environmental Management 57, 109-122. https://doi.org/10.1007/s00267-015-0598-6

Shelanski, H.A., Klein, P.G., 1995. Empirical Research in Transaction Cost Economics: A Review and Assessment. Journal of Law, Economics, \& Organization, 11 (2) 335-361.

Suding, K.N., Gross, K.L., Houseman, G.R., 2004. Alternative states and positive feedbacks in restoration ecology. Trends in Ecology \& Evolution 19, 46-53. https://doi.org/10.1016/i.tree.2003.10.005

Sutcliffe, K.M., Zaheer A., 1998. Uncertainty in the transaction environment: an empirical test. Strategic and Management Journal, 19, 1-23. 
Thom, R.M., 2000. Adaptive management of coastal ecosystem restoration projects. Ecological Engineering 15, 365-372. https://doi.org/10.1016/S0925-8574(00)00086-0

Todd, N., Todd, J., 1994. From eco-cities to living machines: principles of ecological design. North Atlantic Books.

Vaissière, A.-C., Levrel, H., 2015. Biodiversity offset markets: What are they really? An empirical approach to wetland mitigation banking. Ecological Economics 110, 81-88. https://doi.org/10.1016/j.ecolecon.2015.01.002

Vaissière, A.-C., Quétier, F., Bas, A., Calvet, C., Stéphanie, G., Hay, J., Jacob, C., Kermagoret, C., Levrel, H., Malapert, A., Pioch, S., Scemama, P., 2018. France, in: Biodiversity Offsets. Springer, p. 256.

Vesk, P.A., Dorrough, J.W., 2006. Getting trees on farms the easy way? Lessons from a model of eucalypt regeneration on pastures. Aust. J. Bot. 54, 509-519.

Williamson, O.E., 1981. The economics of organization: a transaction costs approach. American journal of sociology, 87 (3) 548-577.

Williamson, O.E., 1985. The economic institutions of capitalism : firms, markets, relational contracting. Free Press, Collier Macmillan, New York.

Yin, R.K., 2017. Case studies research and application: Design and methods. Sage publications, 2017.

Yvrande-Billon, A., Ménard, C., 2005. Institutional constraints and organizational changes: the case of the British rail reform. Journal of Economic Behavior \& Organization 56, 675-699. https://doi.org/10.1016/i.jebo.2004.05.002

Zedler, J.B., 2007. Success: An Unclear, Subjective Descriptor of Restoration Outcomes. Ecological Restoration 25 (3) 162-168.

Zedler, J.B., 2017. What's New in Adaptive Management and Restoration of Coasts and Estuaries? Estuaries and Coasts 40,1-21. https://doi.org/10.1007/s12237-016-0162-5 


\section{Figures}

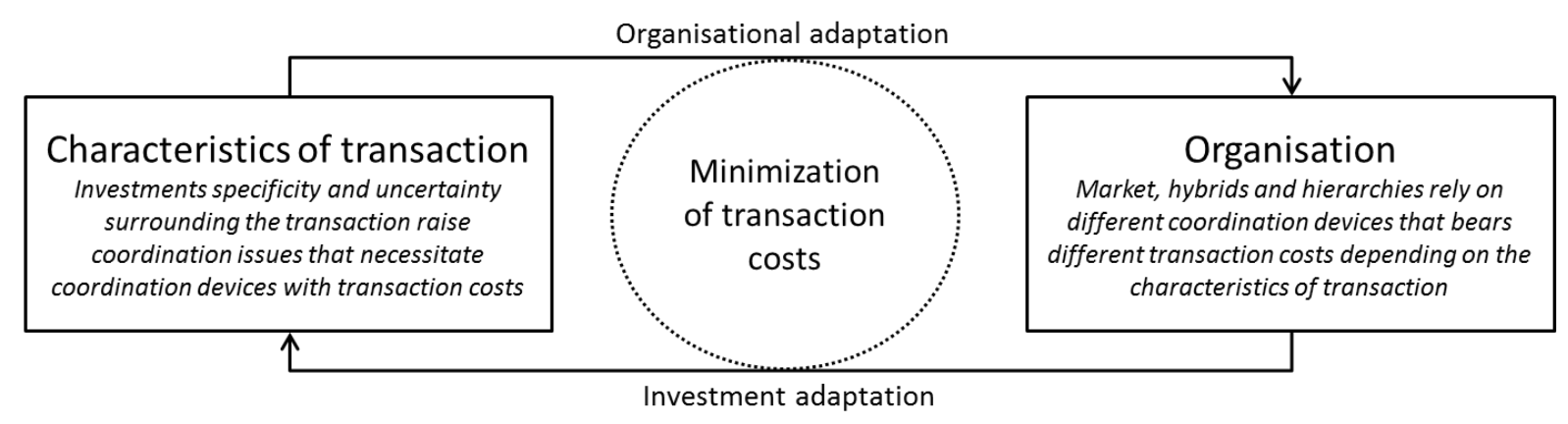

Figure 1 - Illustration of the simultaneity of the design of the transaction and its organization.

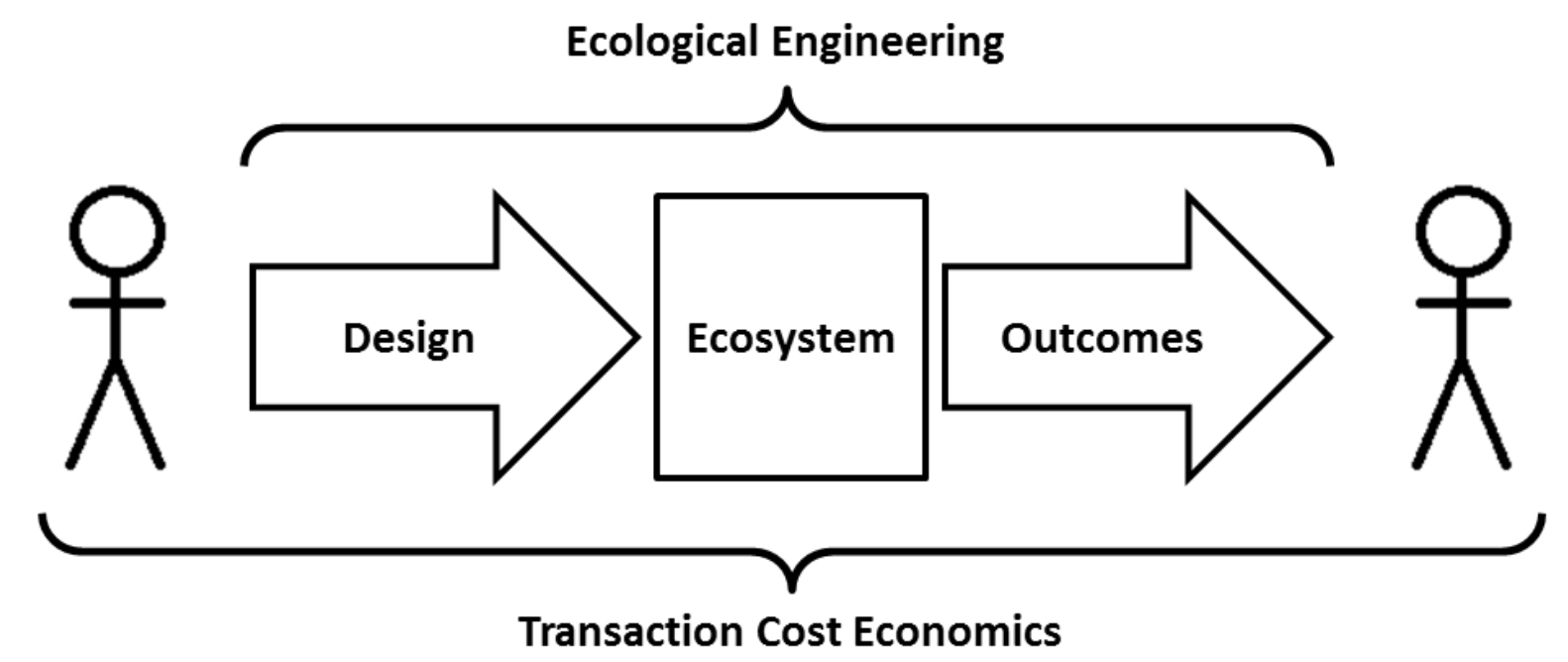

Figure 2 - The unit of analysis in TCE is the transaction (Williamson, 1985) while in EE it is the ecosystem (Mitsch, 2012). 


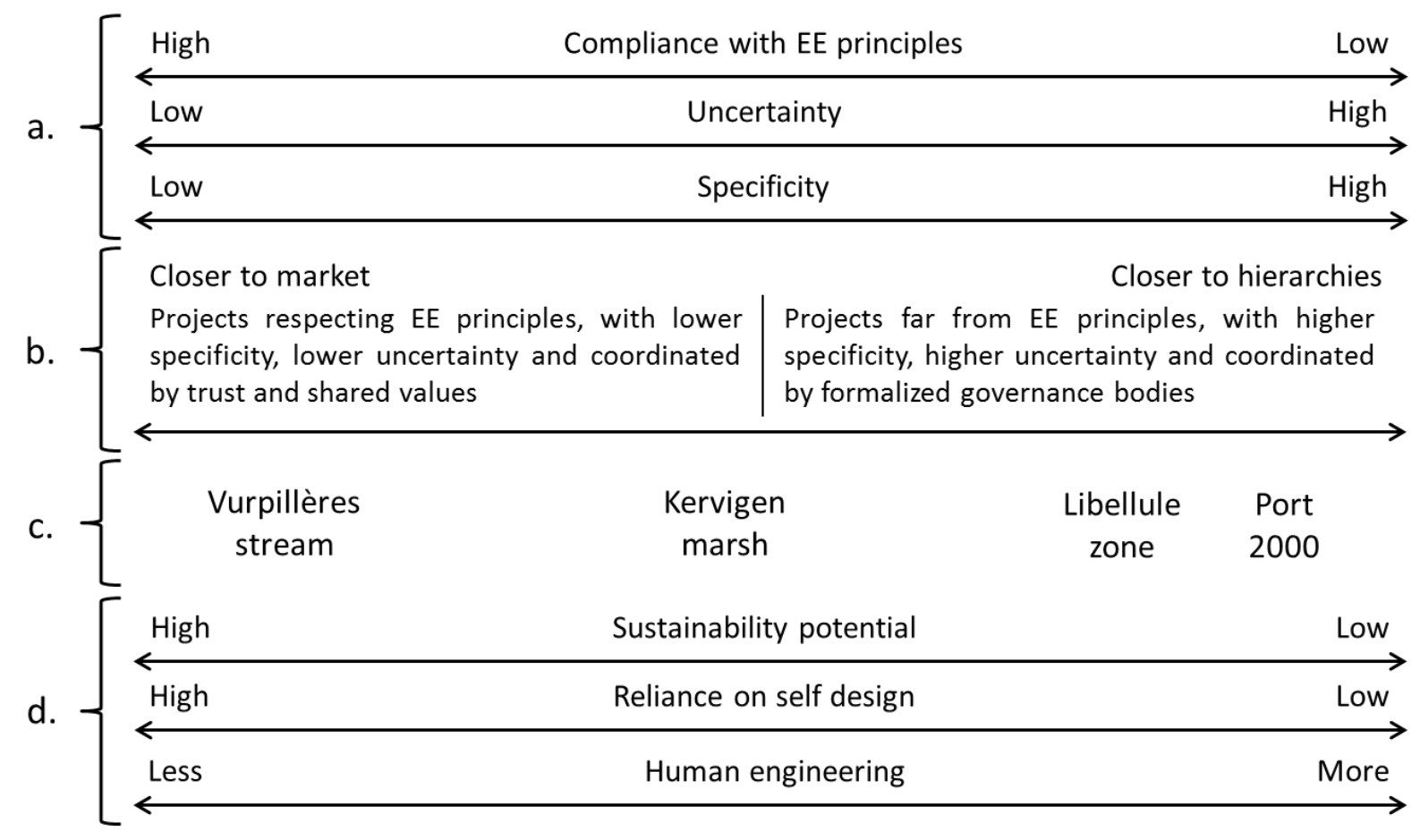

Figure 3 - Analytical framework associating TCE and EE (a. Spectrum of the analytical framework based on compliance with EE principles and sources of transaction cost; b. Link between organizational choice and compliance with EE; c. Position of the four case studies on the spectrum; Spectrum of ecological engineering based on sustainability potential, reliance on self-design and human engineering (from Mitch, 2012))

\section{$\underline{\text { Tables }}$}

Table 1. Summary of the different dimensions of asset specificity in the case of EE projects.

\begin{tabular}{|l|l|l|}
\hline \multicolumn{3}{|c|}{ Specificity of the assets implemented } \\
\hline \multirow{3}{*}{ Natural capital } & Physical specificity & $\begin{array}{l}\text { Complexity and diversity of ecosystem } \\
\text { components and functions across time and } \\
\text { space. }\end{array}$ \\
\cline { 2 - 4 } & Site specificity & $\begin{array}{l}\text { Strong dependency of ecosystem dynamics } \\
\text { on the interactions with their bio-geo- } \\
\text { climatic environment. }\end{array}$ \\
\hline Human capital & Human specificity & $\begin{array}{l}\text { Diversity of knowledge used to create or } \\
\text { restore ecosystems. }\end{array}$ \\
\hline
\end{tabular}




\begin{tabular}{|c|l|c|c|}
\hline & Brand specificity & $\bullet \begin{array}{l}\text { Reputation of actors concerning their } \\
\text { capacity to create or restore ecosystems. }\end{array}$ \\
\hline $\begin{array}{c}\text { Manufactured } \\
\text { capital }\end{array}$ & $\begin{array}{l}\text { Specificity of } \\
\text { manufactured capital }\end{array}$ & $\begin{array}{l}\text { Use of manufactured capital possibly faced } \\
\text { with the issue of specificity. }\end{array}$ \\
\hline
\end{tabular}

Table 2. Effects of compliance with EE principles on the sources of transaction costs.

\begin{tabular}{|l|l|}
\hline Ecological engineering principle. & Effects on the sources of transaction costs. \\
\hline $\begin{array}{l}\text { Targets the broad ecosystem rather than } \\
\text { ecosystem services. }\end{array}$ & $\begin{array}{l}\text { Decreases the specificity of natural capital } \\
\text { Decreases environmental uncertainty. }\end{array}$ \\
\hline $\begin{array}{l}\text { Targets one objective rather than multiple } \\
\text { objectives. }\end{array}$ & Decreases environmental uncertainty \\
\hline Is adapted to its location. & $\begin{array}{l}\text { Decreases site specificity of natural capital. } \\
\text { specificity. }\end{array}$ \\
\hline Minimizes energy and information & Decreases behavioral uncertainty. \\
\hline Is built on shared values. &
\end{tabular}

Table 3. Presentation of the study sites

\begin{tabular}{|c|c|c|c|c|}
\hline & Libellule ${ }^{\circledR}$ zone & $\begin{array}{l}\text { Environmental } \\
\text { measures of Port } \\
2000\end{array}$ & Kervigen marsh & $\begin{array}{l}\text { Vurpillères } \\
\text { stream }\end{array}$ \\
\hline $\begin{array}{l}\text { Geographical } \\
\text { context }\end{array}$ & $\begin{array}{l}\text { Saint-Just and } \\
\text { Saint-Nazaire- } \\
\text { de-Pézan } \\
\text { Pop. } 3068 \\
\text { Languedoc- } \\
\text { Roussillon. }\end{array}$ & $\begin{array}{l}\text { Le Havre } \\
\text { Pop. } 300000 \\
\text { Upper Normandy. }\end{array}$ & $\begin{array}{l}\text { Châteaulin and } \\
\text { Porzay and } \\
\text { surrounding } \\
\text { communities } \\
\text { (CCPCP4) } \\
\text { Pop. } 15000 \\
\text { Brittany. }\end{array}$ & $\begin{array}{l}\text { Labergement- } \\
\text { Sainte-Marie } \\
\text { Pop. } 1000 \\
\text { Franche- } \\
\text { Comté. }\end{array}$ \\
\hline Level of conflict & $\begin{array}{l}\text { Weak - } \\
\text { Consensus on } \\
\text { the interest of } \\
\text { the project. }\end{array}$ & $\begin{array}{l}\text { Strong - Many } \\
\text { competing interests } \\
\text { regarding the } \\
\text { environment. }\end{array}$ & $\begin{array}{l}\text { Medium - } \\
\text { Competition } \\
\text { between } \\
\text { agriculture and } \\
\text { environmental } \\
\text { concerns. }\end{array}$ & $\begin{array}{l}\text { Weak-Project } \\
\text { implemented } \\
\text { in a protected } \\
\text { area. }\end{array}$ \\
\hline Type of action & Creation of a & Home-birds & Producing & Restoration of \\
\hline
\end{tabular}




\begin{tabular}{|c|c|c|c|c|}
\hline & $\begin{array}{l}\text { wetland at the } \\
\text { outlet of a } \\
\text { sewage } \\
\text { treatment plant. }\end{array}$ & $\begin{array}{l}\text { (shorebirds): } \\
\text { creation of an } \\
\text { island in the sea, } \\
\text { creation of a resting } \\
\text { place on dunes. } \\
\text { Production } \\
\text { mudflats: } \\
\text { creation of a } \\
\text { meander. }\end{array}$ & $\begin{array}{l}\text { service for the } \\
\text { assimilative } \\
\text { decrease of } \\
\text { nitrogen. }\end{array}$ & $\begin{array}{l}\text { meanders in } \\
\text { the stream. }\end{array}$ \\
\hline $\begin{array}{l}\text { Actors in } \\
\text { charge of the } \\
\text { project }\end{array}$ & $\begin{array}{l}\text { Private } \\
\text { company }\end{array}$ & Port authority & $\begin{array}{l}\text { Local } \\
\text { government }\end{array}$ & $\begin{array}{l}\text { Nature reserve } \\
\text { manager }\end{array}$ \\
\hline Size of projects & $1.5 \mathrm{ha}$ & $\begin{array}{l}45 \text { ha for the } \\
\text { resting place, } \\
1.5 \text { ha for the island } \\
300 \text { ha for the } \\
\text { meander. }\end{array}$ & 22 ha & $\begin{array}{l}1.1 \mathrm{~km} \text { of } \\
\text { stream }\end{array}$ \\
\hline
\end{tabular}

Table 4. Application of the framework to the Vurpillères stream restoration project

\begin{tabular}{|c|c|}
\hline Compliance with EE & Restoration of the Vurpillères stream \\
\hline $\begin{array}{l}\text { Targets the broad ecosystem rather } \\
\text { than ecosystem services. }\end{array}$ & \multirow{2}{*}{$\begin{array}{l}\text { Restoration of the natural flow of the stream will } \\
\text { allow the ecosystem to evolve naturally into the } \\
\text { desired state. }\end{array}$} \\
\hline $\begin{array}{l}\text { Targets one objective rather than } \\
\text { multiple objectives. }\end{array}$ & \\
\hline Is adapted to its location. & \multirow{2}{*}{$\begin{array}{l}\text { The Design used the traces of the former } \\
\text { meander which were still visible due to } \\
\text { differences in vegetation cover. }\end{array}$} \\
\hline Minimizes energy and information & \\
\hline Is built on shared values. & $\begin{array}{l}\text { The partners shared the same values and } \\
\text { appropriate knowledge for wetlands and stream } \\
\text { restoration. }\end{array}$ \\
\hline
\end{tabular}

Table 5. Application of the framework to the Kervigen marsh rehabilitation project

\begin{tabular}{|l|l|}
\hline Compliance with EE & Rehabilitation of the Kervigen marsh \\
\hline $\begin{array}{l}\text { Targets the broad ecosystem rather } \\
\text { than ecosystem services. }\end{array}$ & Rehabilitation of its purifying capacity for nitrates. \\
\hline
\end{tabular}




\begin{tabular}{|l|l|}
\hline $\begin{array}{l}\text { Targets one objective rather than } \\
\text { multiple objectives. }\end{array}$ & \\
\hline Is adapted to its location. & $\begin{array}{l}\text { Faces eutrophication problems due to the } \\
\text { intensive agriculture in its catchment area. }\end{array}$ \\
\hline Minimizes energy and information. & $\begin{array}{l}\text { Installation of two sluices to manage the water } \\
\text { level. }\end{array}$ \\
\hline Is built on shared values. & $\begin{array}{l}\text { Developing a nature-based solution for } \\
\text { environmental disturbance. }\end{array}$ \\
\hline
\end{tabular}

Table 6. Application of the framework to the Port 2000 environmental measures

\begin{tabular}{|c|c|}
\hline Compliance with EE & Environmental measures of Port 2000 \\
\hline $\begin{array}{l}\text { Targets the broad ecosystem rather } \\
\text { than ecosystem services. }\end{array}$ & $\begin{array}{l}\text { The measures targeted specific functions (habitat } \\
\text { for shore birds and for fishes) and ecosystem } \\
\text { services. }\end{array}$ \\
\hline $\begin{array}{l}\text { Targets one objective rather than } \\
\text { multiple objectives. }\end{array}$ & $\begin{array}{l}\text { The measures targeted multiple objectives that } \\
\text { were sometimes overlapping. }\end{array}$ \\
\hline Is adapted to its location. & $\begin{array}{l}\text { No consideration of the global evolution of the } \\
\text { estuary. }\end{array}$ \\
\hline Minimizes energy and information. & $\begin{array}{l}\text { Preparation studies (hydrodynamic modeling and } \\
\text { laboratory simulations), heavy works (dredging, } \\
\text { civil works, sluice) and considerable monitoring. }\end{array}$ \\
\hline Is built on shared values. & $\begin{array}{l}\text { Bargaining between different communities of } \\
\text { interest to define the measured objectives }\end{array}$ \\
\hline
\end{tabular}

Table 7. Application of the framework to the Zone Libellule creation project

\begin{tabular}{|l|l|}
\hline Compliance with EE & Environmental measures of Port 2000 \\
\hline $\begin{array}{l}\text { Targets the broad ecosystem rather } \\
\text { than ecosystem services. }\end{array}$ & $\begin{array}{l}\text { The objective of the project is to benefit from } \\
\text { services relating to water quality and quantity } \\
\text { regulation. }\end{array}$ \\
\hline $\begin{array}{l}\text { Targets one objective rather than } \\
\text { multiple objectives. }\end{array}$ & $\begin{array}{l}\text { The project seeks to tackle eutrophication issues } \\
\text { (nutrient absorption) but also has an objective }\end{array}$ \\
\hline
\end{tabular}




\begin{tabular}{|l|l|}
\hline & regarding micro-pollutants. \\
\hline Is adapted to its location. & $\begin{array}{l}\text { Project is integrated to local issues } \\
\text { (eutrophication) and its general environment } \\
\text { (Mediterranean climate) }\end{array}$ \\
\hline Minimizes energy and information. & $\begin{array}{l}\text { Preparation studies (soil absorption for habitats } \\
\text { dimensioning), civil works and considerable } \\
\text { monitoring (nutrients and micro-pollutants). }\end{array}$ \\
\hline Is built on shared values. & $\begin{array}{l}\text { Despite global interest and a nature-based } \\
\text { solution, there are divergences between partners } \\
\text { concerning the outcomes of the R\&D project. }\end{array}$ \\
\hline
\end{tabular}

Table 8. Comparative results of the application of the framework to the case studies (Score is 0 when project complies with the EE principle and 1 when it doesn't).

\begin{tabular}{|c|c|c|c|c|c|c|c|c|}
\hline & $\begin{array}{l}\text { Vurpillères } \\
\text { stream }\end{array}$ & & Kervigen mar & & Port 2000 & & \multicolumn{2}{|c|}{ Libellule ${ }^{\circledR}$ zone } \\
\hline $\begin{array}{l}\text { Formalization } \\
\text { governance body }\end{array}$ & Low & & Medium & & High & & High & \\
\hline $\begin{array}{l}\text { Ecosystem vs } \\
\text { ecosystem services }\end{array}$ & Ecosystem & 0 & $\begin{array}{l}\text { Ecosystem } \\
\text { services }\end{array}$ & 1 & $\begin{array}{l}\text { Ecosystem } \\
\text { services }\end{array}$ & 1 & $\begin{array}{l}\text { Ecosystem } \\
\text { services }\end{array}$ & 1 \\
\hline Unique vs. Multiple & Unique & 0 & Unique & 0 & Multiple & 1 & Multiple & 1 \\
\hline $\begin{array}{lll}\text { Adapted } & \text { to } & \text { its } \\
\text { location } & & \\
\text { (Yes vs No) } & & \\
\end{array}$ & Yes & 0 & Yes & 0 & No & 1 & Yes & 0 \\
\hline $\begin{array}{l}\text { Minimizing energy } \\
\text { and information } \\
\text { (Yes vs No) }\end{array}$ & Yes & 0 & No & 1 & No & 1 & No & 1 \\
\hline $\begin{array}{l}\text { Adapted to values } \\
\text { (Yes vs No) }\end{array}$ & Yes & 0 & Yes & 0 & No & 1 & No & 1 \\
\hline Score & 0 & & 2 & & 5 & & 4 & \\
\hline
\end{tabular}




\section{Supplementary material}

Table S1. Number and nature of interviewees

\begin{tabular}{|c|c|c|}
\hline Site & $\begin{array}{l}\text { Nature of the actor } \\
\text { interviewed (Number of } \\
\text { actors) }\end{array}$ & Actors \\
\hline \multirow[t]{7}{*}{ Libellule zone } & $\begin{array}{l}\text { Public institution in charge } \\
\text { of the environment ( } 2 \text { ) }\end{array}$ & $\begin{array}{l}\text { - Water Agency for Rhône, Mediterranean Sea } \\
\text { and Corsica basin (2) }\end{array}$ \\
\hline & Company (2) & - Lyonnaise des eaux (LDE) (2) \\
\hline & Consulting firm (1) & - Biotope \\
\hline & Scientists - experts (3) & $\begin{array}{l}\text {-University of Montpellier (2) } \\
\text {-IRSTEA }\end{array}$ \\
\hline & $\begin{array}{l}\text { NGO for environmental } \\
\text { protection (1) }\end{array}$ & -Mixed association for Or lagoon \\
\hline & Public administration (1) & -Water authority for Hérault department \\
\hline & Local government (2) & $\begin{array}{l}\text {-General } \text { Council }^{5} \text { (GC) of Hérault department } \\
\text { (Technical support services for water sewerage) } \\
\text {-Intercommunal Union responsible for water } \\
\text { management }\end{array}$ \\
\hline \multirow{3}{*}{$\begin{array}{l}\text { Environmental } \\
\text { measures of } \\
\text { Port } 2000\end{array}$} & Public administration (1) & $\begin{array}{l}\text { Environmental management services of the port } \\
\text { of Le Havre }\end{array}$ \\
\hline & Scientists - experts (3) & $\begin{array}{l}\text { - IFREMER } \\
\text { - Member of the scientific council of the Seine } \\
\text { estuary (2) }\end{array}$ \\
\hline & $\begin{array}{l}\text { Public institution in charge } \\
\text { of the environment ( } 3 \text { ) }\end{array}$ & $\begin{array}{l}\text { - Manager of the natural reserve of the Seine } \\
\text { estuary - "Maison de l'estuaire" (MDE) (2) } \\
\text { - GIP Seine Aval }\end{array}$ \\
\hline \multirow[t]{3}{*}{ Kervigen marsh } & Local government (1) & Water Agency for Loire and Brittany basin \\
\hline & $\begin{array}{l}\text { Public institution in charge } \\
\text { of the environment ( } 2 \text { ) }\end{array}$ & $\begin{array}{l}\text { - General Council of Finistère department } \\
\text { (sensitive natural area services) } \\
\text { - Public organisation for the management and } \\
\text { development of the Douarnenez bay ("EPAB") } \\
\text { (previously CCPCP) }\end{array}$ \\
\hline & $\begin{array}{l}\text { NGO for environmental } \\
\text { protection (2) }\end{array}$ & $\begin{array}{l}\text { - Forum for the marshes of the Atlantic } \\
\text { - "GRUMPY Nature" Association }\end{array}$ \\
\hline
\end{tabular}

\footnotetext{
${ }^{5}$ The General Council is the legislative body of the department administrative division; the department is one of the three levels of government below the national level between commune (municipality) and region (Regional Council, RC). The median size of a department is $5965 \mathrm{~km}^{2}$.
} 


\begin{tabular}{|l|l|l|}
\hline & Scientists - experts (1) & - IFREMER \\
\hline $\begin{array}{l}\text { Vurpillères } \\
\text { stream }\end{array}$ & $\begin{array}{l}\text { Public institution in charge } \\
\text { of the environment (2) }\end{array}$ & $\begin{array}{l}\text { - Manager of the natural reserve of the Seine } \\
\text { estuary - "Maison de la réserve" (MDR) } \\
\text { - ONEMA }\end{array}$ \\
\cline { 2 - 3 } & Local government (1) & - Communauté de Communes de Fresne-Drugeon \\
\hline
\end{tabular}

\subsection{Detailed description of the Vurpillères stream restoration project}

The Vurpillères river is located in the upper Jura, in a Nature Reserve of high protection level. It is a little over one kilometer long, supplied by a watershed with no anthropogenic activity and crossing low marshes and peat lands. In the 1960s, with the aim of draining the marshes for agriculture, these streams were channeled. Without releasing usable land, this rectification resulted in a loss of diversity of habitats and species observable on two mains dimensions: (1) the loss of fish habitats and of certain populations and (2) the decrease of the piezometric level and the closing of marshes invaded by woods. A Nature Reserve was established in 1980 and forbid public access to the wetlands and the Vurpillères stream. In its first management plan of the Nature Reserve was elaborated for a 1996-2000 period and included the restoration of the Vurpillères stream through remeandering works as part of a larger program to restore biodiversity in the area.

\subsection{Detailed description of the Kervigen marsh}

The Kervigen marsh is located close to the bay of Douarnenez in south Finistère (Brittany). It is a 22-hectares marsh separated from the sea by a coastal dune. It is crossed by the river Kerharo, its watershed is home of intensive agriculture (maize culture and intensive livestock). In the 1960s, adjustments were made to drain the swamp to intensify agriculture: the rectification of the river, the rising of the dune with concrete columns and the construction of an aqueduct to help evacuate fresh water and prevent salt water reflux back to the river. However all agricultural activity ceased in 1975.

In 1990, because of the intense exposure of Douarnenez Bay to green algae blooms due to eutrophication problems, the Kervigen marsh became the subject of an experiment to take advantage of its capacity to purify nitrates. It is located at the end of the river; consequently 
it is the passing point for all the nitrates of the watershed. It is mainly occupied by reeds which have a high growth rate and can pump a lot of nitrogen. It has a gentle slope facilitating contact with denitrifying bacterium of the superficial layers of the soil. The lower part of the marsh is constituted of brackish water allowing the development of nitrogen consuming phytoplankton. Given the success of this experiment, it was decided to invest in a rehabilitation project.

The objective of the project to rehabilitate the purifying capacity of the marsh complies with EE principle (Table 2). However, environmental and regulatory constraints ${ }^{6}$ fixed specific objectives in terms of results and increased the quantity of energy and information needed. The first stage of works consisted (1) in the implementation of two sluices, to regulate water flows from the river and in the marsh; and (2) in the reinforcement of the river bed to prevent water to go from the marsh back to the river. The second stage consisted in the renaturation of the coastal dune and the destruction of the aqueduct (Figure 4).

Initially, no management plan was anticipated. However, the installation of the sluices required handling the valves to regulate water level in the marsh. Moreover, the excess of nitrate from the watershed can lead to biomass accumulation and nitrogen release. As a result, a management plan consisting in reeds mowing (with rotation to respect habitats for birds) was implemented to export organic matter out of the marsh and prevent its closing. Monitoring of the area was planned to quantify the nitrate absorbed by the marsh with a system of sensors disposed at the inlet and the outlet of the marsh. Additionally, an environmental association conducted some bird inventories and encouraged managers of the area to take better care of the biodiversity.

The project was carried by a federation of municipalities called CCPCP (Community of communes of the country of Châteaulin and Porzay). Before commencement of the works, they had to deal with property rights issues as the marsh was divided into multiple cadastral parcels with different owners. The operation to acquire the marsh was orchestrated by another local authority over 8 years, using a regulatory device which allows acquisition of

\footnotetext{
${ }^{6}$ The water law limits works on streams in order to preserve fish's circulation, as a result the total deviation of the river Kerharo into the marsh - i.e. back to its pristine situation - was impossible and only partial deviation was allowed.
} 
natural area for environmental protection through several mechanisms (from mutual agreement to expropriation). The management of the marsh was entrusted to the CCPCP through an official agreement which can open negotiations every time it has to be renewed. The project involved two other parties: an EE office to build up the files and supervised the works and a construction company that executed the works. The role of the engineering office was important as the project had to comply with environmental and regulatory constraints (Table 3).

The rehabilitation project faces some unexpected problems that can threat the good functioning of the marsh in the long run. First, there is an accumulation of plant residues and sediments carried by the river at the inlet of the marsh, this can obstruct the channel and prevent water from entering the marsh. Second, reed-beds are usually transition ecosystems that tend to accumulating organic matter, silting and evolving into more woody ecosystems. Eventually this phenomenon will lead to the closing of the marsh and to lose its absorption capacities.

Recently the water resource management competencies of the CCPCP site has been transferred - with the management of the marsh - to the organization in charge of watershed management of the downstream bay of Douarnenez, people in charge are the same only their scope of intervention has increased. This organizational change is important for the project because it allows a more effective use of human resources on a more adapted scale for water management. It facilitates coordination and thus reduces transaction costs. Since this transfer, two other projects hydraulic functions rehabilitation inspired by the Kervigen experiment have been implemented in 2015 and 2016. As a result a broader strategy of rehabilitation of purification services by wetlands has been integrated to the watershed management plan. All projects are coordinated by the same actor who exercises a role of leader of the project. This leadership results from the experience capitalized on the Kervigen experiment and from the several policy frameworks regulating environmental management in the area. The Kervigen rehabilitation needs recurring management which has been a problem for the project leader, however since organizational change, the management has been integrated to a broader strategy at the scale of the watershed and has been replicated (Table 3). 


\subsection{Detailed description of the environmental measures of Port 2000}

The Seine estuary refers to the part of the river that is subject to tidal influence. It is a densely populated region and home to a variety of economic activities. The estuary is characterized by the presence of a high biological diversity (birds, fish, etc.) and is included in the Natura 2000 network. It is also protected by the existence of the Nature Reserve of the Seine Estuary. In 1995, the Port of Le Havre starts the first studies for the construction of Port 2000, a port dedicated to container ships with around 4.5 kilometers of dock and 5 kilometers of dyke. With these works the port spread even further on the estuary. As a result, it was decided to implement in balance a series of environmental offsetting measures. They were implemented to increase acceptability of the public for a new port infrastructure, in this way they aimed to address multiple needs from actors with different interests. We will focus on the three main environmental measures: one compensatory measure - a resting area for birds - and two accompanying measures - an islet resting place for birds at the outlet of the estuary and the creation of a meander for mudflat rehabilitation (Figure 5).

The Seine estuary is a prime territory for shorebirds, given its location on the Western Europe migration route and given the richness and the diversity of its natural or semi-natural habitats. Once it has been decided that the works of Port 2000 would imply the destruction of a former deposition chamber colonized by shorebirds as a repository during high tide, authorities in charge of the project planned a measure assumed to compensate the functions lost with this destruction. The repository on dune has been built on a traditional engineer vision, i.e. with a view to control a maximum of environmental variables in order to maximize the "production" of biodiversity; in practical it implied a set of punctual works. After repeated failures, planners gave up the idea of a superposition of objectives to adopt an adaptive management of the area and the association of other measures - for example it has been decided to forbid birds hunting near the area in order to limit disturbances.

The creation of the islet resting place also aims at offering new areas for shorebirds. This project has been conceived by a great number of actors with very different personal objectives: an organization of ornithologist, institutional actors and port's engineers. During the conception phase, the project faced a lot of critics. In order to content all parts, the 
objectives of the projects became more and more complex and numerous (be a place for three species of shorebird, be one islet at low tide and divided in three separated islet at high tide, be highly resistant against currents, be exposed to sedimentation in order to create a feeding zone and be able to shelter mammals on a gentle slope). The works lasted 165 days and needed 600 travels of watercrafts. The expected species are observed but not to the expected level, the repository islet fulfill its function but with a reduce efficacy (Aulert et al., 2009).

Mudflats play a very important role in the functioning of the estuary as they constitute the basis of an important benthic activity supporting a trophic chain that feed fishes at high tide and shorebirds at low tide. The gradual urbanization led to a regression of mudflat at the pace of 20 hectares par year between 1980 and 2000. Therefore, in order to limit the progression of herbs and woods on the north shore of the estuary, it has been decided to implement an ambitious project of rehabilitation that comprised mainly the creation of a meander under the Normandy Bridge. The preliminary phase consisted in establishing a model of the potential hydrodynamic effects associated to different scenarios of rehabilitation with a view to the apparition of 100 hectares of functional mudflats. The works lasted 12 months and led to the dragging of 1,800,000 cubic meters of silt and sand for a meander of around 2,800 meters length and 100 meters width. The ecological objective pursued by the project has not been reached, only 60 hectares of functional mudflats have appeared on an unexpected area. One possible reason is that the design didn't take into account a change in the Port 2000 infrastructure, creating a disruption of hydrodynamics and this unexpected result.

In summary, the different measures had different targets that let very little space for autoorganization and natural evolution of the ecosystems (Table 2). Moreover because of the presence of high anthropogenic pressure, the estuary is exposed to high uncertainty. Finally, ecosystem design ended very far from natural condition and necessitated high level of engineering knowledge: (1) before the works with sophisticated model to anticipate hydrodynamics conditions generating high transaction costs; (2) during the works because of the magnitude of the project; (3) after the work with intensive monitoring to control the performances. As a result, environmental measures of Port 2000 consisted in projects with very high specificity and high uncertainty. 
These environmental measures took place in a complex institutional environment (Table 3); indeed global objectives have been defined through a Public Debate - a consultation device aimed at improving association of public to the elaboration of major projects - resulting in 42 meetings during 4 months. Moreover, there is at the scale of the estuary a committee of experts that deliver advisory opinion for every decision that affects the estuary. In this larger context, projects were operated by three different parties. Firstly, the port administration, it has to implement the environmental measures as negotiated during the consultation for Port 2000 works, it is responsible for the management of the environment on its territory but has few expertise in environmental science. Secondly, a consultant that brings its expertise to help with the design of the project, in the case of the islet or the meander the port contracted a specialized engineering consultant that developed a very elaborate model to better anticipate hydrodynamic evolution of the estuary after the works for Port 2000. Third, the constructor is contracted through public tenders to implement the works. Each party is not limited to a single and well identified actor, for example in the case of the islet the role of consultant was held by a group of actors (NGO, public administration, port authorities and an external company) similarly in the case of the meander the works were conducted by a consortium of three companies. We can identify a very formalized "governing body" for the project: the port administration coordinates the project, seeks advices from the expert committee of the estuary but keeps everything very formal as it engages its responsibility. In the end, project effectiveness is highly contested. This is due to the organization of the project that added objectives to satisfy a maximum of actors without consideration of their compatibility. Moreover the project was surrounded by very high uncertainty that should have imply flexibility and time for learning by doing incompatible with the objective of the project. Environmental measures are still contested (both for their results and for the way they were implemented) and potentially increase the future tensions around the management of Natura 2000 sites (Vaissière et al., 2018).

\subsection{Detailed description of the creation of the Libellule ${ }^{\circledR}$ Zone}

In 2007, the towns of Saint-Just and Saint-Nazaire-de-Pézan undertook the renovation of their wastewater treatment plant (WWTP). Because of their location in the watershed of a protected Mediterranean lagoon exposed to eutrophication problems (the Or lagoon), 
financial partners (municipalities, local government and water agency) proposed to create a constructed wetlands in order to apply tertiary treatment while securing the rejection of the WWTP. The company in charge of the WWTP - through a public service delegation agreement - offered to support the costs of establishing the constructed wetland in exchange of the opportunity to implement the experimental Libellule ${ }^{\circledR}$ zone in place of the original project which merely consisted of a pond planted with reeds. This new project, in addition to the initial objectives, included a research program on micro-pollutants and the implementation of an ambitious monitoring system to measure the decrease of these micropollutants. The Libellule ${ }^{\circledR}$ zone has been operational since 2009; some of the water leaving the WWTP reaches a succession of wetland habitats - phytoplankton basin, reed marsh, meandering zone, anastomosing array and free zone - complemented by a humid meadow, an alluvial zone, a brush planted with trees and a sand filter (Figure 6).

The creation of the Libellule ${ }^{\circledR}$ zone relies on the use of the functioning of ecosystems to provide selected ecosystem services. If this objective is compatible with $E E$, the project is exposed to specific constraints that can lead to optimizing several ecosystem services from different processes which had implication on the design and the need for particular monitoring and management (Table 2). Works consisted of earthwork to create the slope for optimal length of stay of water in each compartment; implementation of plant cover that are important in the short term to protect bare soil from erosion by the local severe storms and in the long term for its structuring role toward managing flows, fixing micro-organisms and offering habitats for fauna.

To this investment was associated a costly monitoring protocol to assess performances of the Libellule ${ }^{\circledR}$ zone in terms of mitigating nitrogen and phosphorus and in eliminating micropollutants. The second is very controversial because monitoring was conducted only into the water and only for targeted molecules. Indeed, it is not enough to conclude about the "performances" of Libellule ${ }^{\circledR}$ zone in eliminating micro-pollutants as very little is known about what happened to them.

Concerning management, parties adopted a laissez-faire policy, but the specific objective of Libellule ${ }^{\circledR}$ zone needs an active management plan for two reasons. First, the wetland can face non-recurring events that have a negative impact on the functioning of the wetland 
(e.g. an apparition of azolla covering the surface of one basin could have led to phenomenon of dystrophy if not treated). Second, operator needs to maintain the wetland in a given functional state with operation of cutting herbs that can obstruct meanders or dredging ponds to prevent clogging phenomenon.

This monitoring was associated to a steering committee and involved a lot of partners from different spheres: actors from the operating company, scientists from different area of expertise (hydrobiology, environmental engineering, etc.) and public players that are implied in water regulation (local government and water agency). Each sphere has its own objective and they can be contradictory, for example the objective of the scientist will be to communicate about the research associated to the project which is in conflict with the objective of the operating company which is to keep secret the expertise and knowledge accumulated in order to create a competitive advantage against its rivals. Similarly the operator wants to use this committee to obtain a stamp from regulators and scientists that could promote their expertise to future buyers. Despite these difficulties to comply with the values of the different type of actors involved (especially with the scientists involved in the monitoring), all actors were united behind the interest to develop such complex constructed wetlands instead of classical ponds with reeds.

The project is coordinated by a formal "governing body": a steering committee that integrates all the parties involved that take all the decisions and try to satisfy all the opinions (Table 3). The company in charge of the initiative tries to keep a maximum of information integrated in its structure (preparation, modeling and works) as it will constitute valuable knowledge. However it has to deal with other actors that also brought resources. Property rights over the site are still in the municipality's hands - who is still liable for every problem coming from the WWTP. In the same way, a lot of the expertise and extra funding for the R\&D program is coming from third parties (public actors or researchers). This project is characterized with a relatively high specificity leading to very high transaction costs. However, most of these transaction costs are related to the R\&D nature of the project (formal coordination, confidentiality control and high monitoring around the control of the performances). In order to replicate this experiment, the project investor would have to reduce transaction cost, an opportunity is to include the transaction in the governance of the WWTP, in this way project manager could benefits from both economies of scale and 
added value to WWTP. This is the axis of communication chosen by the investors and that have allowed them to realize other similar investment in France and abroad. 